\title{
An Overview of B-1 Cells as Antigen-Presenting Cells
}

\author{
Ana F. Popi*, leda M. Longo-Maugéri and Mario Mariano \\ Departamento de Microbiologia, Imunologia e Parasitologia, Escola Paulista de Medicina, Universidade Federal de \\ São Paulo, São Paulo, Brazil
}

The role of B cells as antigen-presenting cells (APCs) has been extensively studied, mainly in relation to the activation of memory $T$ cells. Considering the $B$ cell subtypes, the role of B-1 cells as APCs is beginning to be explored. Initially, it was described that B-1 cells are activated preferentially by T-independent antigens. However, some reports demonstrated that these cells are also involved in a T-dependent response. The aim of this review is to summarize information about the ability of B-1 cells to play a role as APCs and to briefly discuss the role of the BCR and toll-like receptor signals in this process. Furthermore, some characteristics of B-1 cells, such as natural IgM production and phagocytic ability, could interfere in the participation of these cells in the onset of an adaptive response.

\section{OPEN ACCESS}

Edited by:

Nichol E. Holodick,

The Feinstein Institute for

Medical Research, USA

Reviewed by:

Adam Cunningham,

University of Birmingham, UK

Sylvie Bertholet,

GlaxoSmithKline Vaccines, Italy

${ }^{*}$ Correspondence:

Ana F. Popi

afpopi@unifesp.br

Specialty section:

This article was submitted to B Cell Biology,

a section of the journal

Frontiers in Immunology

Received: 13 November 2015

Accepted: 28 March 2016

Published: 11 April 2016

Citation:

Popi AF, Longo-Maugéri IM and Mariano M (2016) An Overview of B-1 Cells as

Antigen-Presenting Cells.

Front. Immunol. 7:138. doi: 10.3389/fimmu.2016.00138
Keywords: B-1 cells, APCs, BCR, TLR, autoimmune diseases

\section{INTRODUCTION}

Murine B-1 cells are known as innate B lymphocytes. However, the classification of these cells as B cells raised many questions, including whether this B cell subtype works in a similar or different way than its counterpart, conventional B-2 cells. Several reviews discuss differences between these two cell populations, regarding to their ontogeny, anatomical localization, antibody repertoire, antigen stimulus, and role in the immune response (1-6). The two major subsets of B cells, B-2 and B-1 cells, are defined by the differential expression of CD5 (7). Along with the presence of CD5 on their surface, B-1 cells are further differentiated from B-2 cells by the expression of CD11b, $\mathrm{IgM}^{\text {high }}$, IgD ${ }^{\text {low }}$, and the absence of $\mathrm{CD} 23$ (8). Furthermore, CD5 expression also subdivides the B-1 cells into two different subsets, B-1a cells, which are $\mathrm{CD}^{+}$, and B-1b cells, which are $\mathrm{CD}^{-}$ $(2,8)$. B-2 cells are produced in the bone marrow from hematopoietic stem cells and migrate to the secondary lymphoid organs as immature B cells. In these organs, they differentiate into follicular and marginal zone B cells $(9,10)$. B-1 cells are mainly present in the peritoneal and pleural cavities and constitute only a small fraction of the B cells in the spleen (11). B-1 cell origin and development occur primarily during the fetal stage from distinct precursors from B-2 cells $(12,13)$. Recently, Ghosn et al. (14) described that HSCs sorted from adult bone marrow and transferred to lethally irradiated recipients clearly give rise to B-2 and B- $1 \mathrm{~b}$ cells but do not detectably reconstitute B-1a cells (14). Furthermore, it has been postulated that the B-1a lineage derives independently from a hematopoietic stem cell (14). These B cell subsets specialize in the recognition of diverse antigens; consequently, they provide distinct immune effector functions. B-1a cells play a role in innate immunity via their contribution to natural antibodies, whereas B-1b cells are critical in the development of IgM memory cells (1). B-1a cells respond rapidly to T-cell-independent antigen (15). B-1a cells are also known to produce most of the natural antibodies in the serum $(16,17)$. Despite this, B-1 cell antibodies have been found to be reactive to self-antigens, and hyperplasia 
of the B-1 cell population has been found in some autoimmune diseases $(18,19)$. The antibody production by B-1b cells has been poorly investigated. By contrast, the B- 2 cell response to protein antigens is well described and elicits a T-cell-dependent immune response.

There are few reports about the possible roles each B cell subtype exerts in the immune response by acting as APCs. Although the majority of articles indicate the participation of B-1 cells in recognizing the T-cell-independent antigen, some reports demonstrate their role as antigen-presenting cells (APCs) (20-25). This role is extremely important because it could be one of the functions that have allowed the maintenance of B-1 cells through phylogenetic evolution. Furthermore, a more comprehensive status regarding this function could provide explanations concerning the role of B-1 cells in the immune response and in some diseases, such as autoimmune diseases.

\section{ANTIGEN-PRESENTING B-1 CELLS}

Ron et al. (26) first demonstrated evidence of the role of B-2 cells in the $\mathrm{CD}^{+} \mathrm{T}$ cell response by showing a failure of proliferative $\mathrm{T}$ cell responses to protein antigens in B cell-depleted mice. To determine whether $\mathrm{B}$ cell deficiency caused the $\mathrm{T}$ cell response impairment in these mice, the authors showed that splenic cells and peritoneal macrophages were able to stimulate $\mathrm{T}$ cell response in vitro. Although the first description of this occurred in the beginning of the $80 \mathrm{~s}$, the priming of $\mathrm{T}$ cells by B lymphocytes remains controversial (26-30), and scarce information exists about the role of other B cell subtypes. It has been postulated that the antigen-presentation capacity of antigen-specific B-2 cells is reserved for the re-activation of memory T cells $(29,31,32)$. This could be, in part, attributed to the kinetics of the response of B-2 cells, considering that the activation of these cells by a specific antigen takes several days. In this case, activated B- 2 cells might encounter their cognate primed $\mathrm{T}$ cell and then play a role in their function as APCs (33-35). In this condition, activated B-2 cells are optimal APCs because they drive the T lymphocyte response to specific antigens $(36,37)$ and are able to modulate the polarization of $\mathrm{T}$ cells by cytokines.

As mentioned before, B-1 cells respond to T-independent antigens and are responsible for the production of natural antibodies, mostly IgM. These cells do not effectively participate in T-dependent responses [reviewed by Berland and Wortis (1)]. Despite this, some reports provide evidence that B-1 cells also stimulate $\mathrm{T}$ cells and respond to $\mathrm{T}$-dependent antigens (20). Combined adoptive transfer experiments of OVA-pulsed peritoneal-derived B-1 cells and CFSE-labeled T cells demonstrated that B-1 cells are able to stimulate $\mathrm{T}$ cell proliferation. Furthermore, antigen presentation by B-1 cells to OVA-specific T cells was also demonstrated in vitro (20). Constitutive expression of MHC class-II, CD80, and CD86 by B- 1 cells validated these findings (22). Furthermore, the presence of an inflammatory stimulus or a specific antigen augments these molecules on the surface of B-1 cells $(22,38,39)$. Zimecki and Kapp (24) and Zimecki et al. (25) showed that B-1 cells present Ags to Ag-specific T cells and induced more efficient proliferation than conventional B cells.

\section{BCR AND TLR AS ANTIGEN UPTAKE PLAYERS ON B-1 CELLS}

B cells have two primary pathways for their activation as APCs, which occurs through BCR or the germline-encoded PAMP receptors (40-42). BCR plays a dual role in B-2 cell activation: (1) the ligation of specific antigens in the BCR induces a signaling cascade that leads to the activation and proliferation of B-2 cells (43) and (2) the BCR-antigen interaction results in internalization and processing of the antigen. Although they are not completely elucidated, the BCR signals in B-1 cells are quite different than in B-2 cells (44-46). B-1 cells show a failure to be activated after BCR engagement, and multiple mechanisms appear to be involved in maintaining B-1 cells in an anergic state. One such mechanism involves Lyn, which acts by phosphorylating ITIMs on inhibitory receptors, leading to the recruitment of PTPs that antagonize the BCR-mediated activation of PTKs. IL-10 also plays a key role in controlling the expansion of self-reactive B-1 cells. CD5 was also indicated as a negative regulator of BCR signals in B-1 cells. Defects in the negative regulatory mechanisms may account for the accumulation of B-1 cells and autoantibodies in autoimmune diseases. However, in an infectious disease, signals from CD40 and high-dose TLR ligands can overcome the anergic state of B-1 cells, enabling their activation during infection (44-46).

Interestingly, in addition to the fact that a non-functional BCR results in a defect in the activation of B-2 cells, it also causes a failure in the $\mathrm{T}$ cell response (26). This information supports the idea that internalization of the antigen by the BCR is important to the APC function of B-2 cells. It has been demonstrated that the absence of $\mathrm{B}$ cell antigen presentation, due to the lack of $\mathrm{MHC}$ expression or a non-functional BCR, results in a defect in the memory CD4 response. Barr et al. (40) demonstrated that the TLR activation of B-2 cells is important for the generation of the primary Th1 response in an antigen presentation-independent process. However, BCR recognition and B cell antigen presentation are absolutely required for the development of Th1 memory cells and hence confer protective immunity to Salmonella. With respect to B-1 cells, Gao et al. (47) demonstrated that the antigen specificity of the BCR was involved in the uptake of Salmonella by B-1 cells, and the number of phagocytic peritoneal B-1 cells from TgVH3B4 mice was almost threefold higher than that observed in the littermate control mice. Based on these results, it could be suggested that the BCR is essential for the phagocytosis of bacteria by B-1 cells and is also important for enabling these cells to exert APC functions.

Conversely, specific antigen uptake by the BCR and the activation of $B$ cells by the TLRs connect them to an innate phase of the immune response. B-2 cells express many of the TLRs $(42,48,49)$, and TLR4 and TLR9 are the most studied. TLR expression is quite different among the B cells subsets. B-2 cells express less TLR2, 6, and 7 and equal amounts of TLR1, 4, 5, and 9 compared to other $\mathrm{B}$ cell subsets. Interestingly, MZ B cells and B-1 cells show a clear similarity in TLR expression, displaying increased levels of TLR2, 6 , and 7, along with decreased levels of TLR8 (50).

Intriguingly, differences regarding their response to TLR agonists were found between naive murine $B$ cell subsets. Triggering of the TLR induces B-1, but not B-2, cells to differentiate into 
fully mature plasma cells (51). Based on these data, the authors proposed that during a natural infection, the TLR stimulation leads to the production of protective natural antibodies by the B-1 cells, which could control the microbial load until the adaptive arm of the immune response becomes fully functional.

It is well known that LPS functions as a B-2 cell mitogen, leading to the activation and polyclonal expansion of these cells, independent of BCR reactivity. In vitro, B-1 cells proliferate and produce antibodies in response to TLR engagement. Certain TLR ligands, including Pam3CSK (TLR1/TLR2), MALP2 (TLR2/ TLR6), LPS (TLR4), and R848 (TLR7/TLR8), are able to induce B-1 cell proliferation, whereas others, including flagellin (TLR5) and polyIC (TLR3), are not (51). The proliferation of B-1 cells in response to LPS is stronger than in B-2 cells; however, it is less intense in response to $\mathrm{CpG}$.

Some reports show evidence that stimulation of the TLRs in $\mathrm{B}$ cells impacts in the $\mathrm{T}$ cell response via not only the secretion of diverse cytokines but also the increased expression of several costimulatory molecules involved in the T:B cell interaction, such as MHC-II, CD40, CD80, CD86, and others (42, 49, 52-54). Interestingly, our group has described the adjuvant effect of Propionibacterium acnes on the expression of the TLR by B-1 cells (39) (Gambero et al., submitted). P. acnes, a Gram-positive bacillus, is the major constituent of the normal human adult skin microflora (55). As already demonstrated in clinical and experimental models, a dead $P$. acnes suspension modulates the innate and acquired immune responses, including an increase in antibody responses and phagocytic and tumoricidal macrophage functions (56-63). An important effect of P. acnes is its capacity to direct the immune response toward a Th1 or Th2 response (64, 65). $P$. acnes interferes in the B- 1 cell APC activity through the toll-like receptors (TLRs), principally TLR2 and TLR9 (66-68). Interestingly, the bacterium increased the expression of MHC-II, CD80, CD86, CD40, TLR2, TLR4, and TLR9 by the B-1 cells (39). It was also confirmed that the adjuvant effect induced by $P$. acnes on the B-1 cells is mediated by TLR2 (Gambero et al., submitted). $P$. acnes increases the number of B-1 cells in vitro and in vivo, induces their early differentiation into phagocytes in vitro, and increases the phagocytic ability of these cells (39) (Gambero et al., submitted). The direct influence of $P$. acnes on antigen presentation by B-1 cells is under investigation. Furthermore, LPS stimulus also increases the differentiation of B-1 cells into phagocytes in vitro and in vivo $(69,70)$; however, whether the stimulus increases the APC activity is not yet clear.

Another important point in TLR signaling in B cells is cytokine production. Barr et al. (41) demonstrated that the binding of TLR2, TLR4, and TLR9 in B cells induces B-2 cells to secrete IFN-gamma and IL-6. Interestingly, TLR engagement in B-1 cells augmented the secretion of the proinflammatory cytokine IL-6 and the anti-inflammatory cytokine IL-10 (71), which have antagonistic effects in the course of the immune response. However, both cytokines are important to B-1 cell proliferation and viability. IL- 6 is related to antibody production by B- 1 cells in autoimmune disease, and IL-10 plays a negative role in the activation of the BCR. It could be speculated that the secretion of both cytokines after TLR signals could be important in the control of the B-1 cell response in the onset of inflammation and could prevent the development of an exacerbated response to self-antigens.

\section{THE ROLE OF CD80/CD86 IN B-1 CELLS}

Some studies point to the role of certain molecules in the induction of $\mathrm{CD}^{+} \mathrm{T}$ cell polarization by B-1 cells. B-1 cells express elevated levels of CD80 and CD86 in comparison to B-2 cells (72). Zhong et al. (73) demonstrated that CD86 blockage markedly reduced the capacity of B-1 cells to stimulate alloreactive $\mathrm{T}$ cells. Interestingly, the same treatment increased the generation of Treg cells after antigen presentation by B-1 cells. However, anti-CD80 antibody treatment had much less of an effect on the capacity of B-1 cells to stimulate alloreactive T cells and on the generation of Treg cells than did anti-CD86 antibody treatment (73). Anti-CD86 treatment also partially inhibited the induction of Th17 cells (23). In agreement with these findings, De Lorenzo et al. (38) demonstrated that OVA-presensitized B-1 cells were less able to induce $\mathrm{T}$ cell proliferation than naive $\mathrm{B}-1$ cells. Additionally, these authors described that OVA-presensitized B-1 cells express high levels of MHC-II molecules compared to naive B-1 cells and that the expression of CD86 was lower.

Interestingly, the CD86 molecule may also provide the costimulatory signal in fish B cell, similar to B-1 cells (74). These results indicate that even in primitive vertebrates, $\mathrm{B}$ cells may act as pivotal initiating APCs in priming naive T cells, similar to DCs and macrophages in mammals. Elucidating how antigen presentation occurs in ancient vertebrates and in different B cell subtypes in mammals may contribute to the understanding of the evolutionary history of B cell populations, such as the origin of the B-1 subset, and of the evolution of the adaptive immune response.

\section{T CELL POLARIZATION BY B-1 CELLS}

Although some authors have described the production of cytokines by B-1 cells, scarce literature exists about the polarization of $\mathrm{T}$ cells by them. Some reports about this pointed out that B-1 cells favor Th17 polarization $(23,73)$.

Comparing the APC activity of B-2 cells and peritoneal B-1 cells, Margry et al. (20) demonstrated that peritoneal B-1a cells increase the percentage of IL-10-, IFN- $\gamma$-, and IL-4-producing $\mathrm{T}$ cells. Furthermore, peritoneal B-1a cells present antigens to $\mathrm{CD}^{+} \mathrm{T}$ cells in the peritoneal cavity, which is totally distinct from the milieu, where antigen presentation by conventional $\mathrm{B}$ cells occurs. The authors also show that the activation of $\mathrm{CD}^{+}$ $\mathrm{T}$ cells by peritoneal B-1a cells promotes a more intense proliferation compared to conventional B cells. Although peritoneal $\mathrm{B}-1 \mathrm{a}$ cells induce activated $\mathrm{T}$ cells to produce larger amounts of IL-10, IFN- $\gamma$, and IL-4 in vitro (20), B-1a cells derived from the spleen preferentially induce IL-17 production by $\mathrm{T}$ cells. In agreement with this, other authors also demonstrated that B-1 cells preferentially induce Th1 and Th17 differentiation in vivo (73). This strong inflammatory response elicited by the B-1 cells could be related to their role in the autoimmune diseases (21). Interestingly, in cultures for the generation of Treg cells, when B- 1 cells were used as the APCs, fewer Foxp $3^{+}$Treg cells were 
generated in comparison to cultures where splenic B-2 cells were used (73). The failure to generate Treg cells, in addition to the induction of a Th1/Th17 profile by the B-1 cells, could be one of the mechanisms of the autoimmune profile of B-1 cells. However, this hypothesis is only a speculation, because the induction of the Th profile by the B-1 cells needs to be investigated in more detail and in different infection/disease models.

Other important point to be discussed is about the localization of antigen presentation by B-1 cells. Despite the migration of B-1 cells to inflammatory milieu and other organs (75-77), it was not well documented if it is necessary that these cells migrate to secondary lymphoid organs to exert APC role. Interestingly, Margry et al. (20) demonstrated that peripheral T cells visit the peritoneal cavity and engage with antigen presented by B-1 cells in this location. In this context, we could postulate that APC role of $\mathrm{B}-1$ cells could be more direct to reactivate memory T cells than priming naive $\mathrm{T}$ cell since that the majority of $\mathrm{T}$ cells found in the peritoneal cavity is memory $\mathrm{T}$ cells.

\section{THE ROLE OF B-1 CELL ANTIGEN PRESENTATION IN AUTOIMMUNE DISEASES}

As mentioned before and in the literature, the TLR and BCR signals are important in the assembly of the adaptive response. In an early stage, TLR signals drive the secretion of cytokines by the APCs and contribute to the expression of some molecules that are important in the antigen-presenting process. Later, BCR-mediated uptake is important to the antigen presentation by $\mathrm{B}$ cells and the maintenance of memory $\mathrm{T}$ cells. In addition to its importance in the secondary response during an infection, this also could be a mechanism that induces autoimmune disease. In fact, the involvement of BCR/TLR signals in driving T cells in lupus (78) and EAE has already been described $(21,79)$.

Sato et al. (21) described an increase in the B-1 cell population in the disease target organs of a murine model of lupus. These authors demonstrated that B-1 cells aberrantly migrate into the thymus during the development of lupus nephritis and that B-1, but not B-2, cells induce the activation and expansion of thymic $\mathrm{CD}^{+} \mathrm{T}$ cells in the presence of IL-2. Considering that B-1 cells often recognize self-antigens and express higher levels of costimulatory molecules, their role in activating the autoreactive TCR should be considered. These findings may provide a novel understanding of the mechanism for the loss of immunological tolerance in the development of autoimmune disease.

\section{REFERENCES}

1. Berland R, Wortis HH. Origins and functions of B-1 cells with notes on the role of CD5. Annu Rev Immunol (2002) 20:253-300. doi:10.1146/annurev. immunol.20.100301.064833

2. Hayakawa K, Hardy RR, Parks DR, Herzenberg LA. The "Ly-1 B" cell subpopulation in normal immunodefective, and autoimmune mice. J Exp Med (1983) 157(1):202-18. doi:10.1084/jem.157.1.202

3. Herzenberg LA. Toward a layered immune system. Cell (1989) 59(6):953-4. doi:10.1016/0092-8674(89)90748-4

\section{CONCLUDING REMARKS}

B-1 cells have peculiar features, such as a mixture of innate and lymphoid cell properties. As mentioned here, some authors describe similarities between B-1 cells and primordial B cells in ancient vertebrates (74). As described for teleost fish B cells, B-1 cells are phagocytic cells $(6,69,70,75)$ and have microbicidal activity $(80,81)$, similar to DCs and macrophages in mammals. Furthermore, several reports indicate that B-1 cells may play a role as initiating APCs, not only in the maintenance of memory $\mathrm{T}$ cells, similar to conventional B cells, but also in priming $\mathrm{CD} 4^{+}$ $\mathrm{T}$ cells. It is important to reinforce that B-1 cells produce a majority of the IgM natural antibodies. In this context, we postulate that these antibodies could form immunocomplexes with selfantigens and that B-1 cells could internalize these, leading to intense antigen presentation to T cells. A speculative scenario was proposed, in a continuous inflammatory stimulus, elevated levels of IL-6 increased induce expansion of B-1 cell population, and also increased the B-1-cell antibody production. Furthermore, the CD86 expression by B-1 cells is also augmented, and it favors the B-1 cell APCs function and also the induction of Th17 profile. Considering that B-1 cells produce mainly self-reactive antibodies, the increased levels of the B-1 cell-derived antibodies could leave to an increase in the antigen uptake by these cells and also augment in antigen presentation to self-reactive TCR, which could lead finally to an induction of autoimmune diseases.

In conclusion, further detailed investigations should be conducted to elucidate the role of B-1 cells in priming $\mathrm{T}$ cells during an infectious disease. Several strategies have been developed considering the use of APCs in therapies for which amplification of the immune response is necessary; thus, B-1 cells might also be considered in this context. Furthermore, the participation of these cells in the breakdown of self-tolerance should also be considered.

\section{AUTHOR CONTRIBUTIONS}

AFP conceived the idea and topic of the review, wrote and discussed the text with other authors. IMLM and MM discussed the ideas, read and made suggestions in the final text.

\section{FUNDING}

This review was supported by FAPESP grant number 2008/58561-0 and 2015/01986-2.
4. Montecino-Rodriguez E, Dorshkind K. New perspectives in B-1 B cell development and function. Trends Immunol (2006) 27(9):428-33. doi:10.1016/j. it.2006.07.005

5. Montecino-Rodriguez E, Leathers H, Dorshkind K. Identification of a B-1 B cell-specified progenitor. Nat Immunol (2006) 7(3):293-301. doi:10.1038/ni1301

6. Popi AF. B-1 phagocytes: the myeloid face of B-1 cells. Ann N Y Acad Sci (2015) 1362:86-97. doi:10.1111/nyas.12814

7. Herzenberg LA, Stall AM, Lalor PA, Sidman C, Moore WA, Parks DR. The Ly-1 B cell lineage. Immunol Rev (1986) 93:81-102. doi:10.1111/j.1600065X.1986.tb01503.x 
8. Tung JW, Mrazek MD, Yang Y, Herzenberg LA, Herzenberg LA. Phenotypically distinct B cell development pathways map to the three B cell lineages in the mouse. Proc Natl Acad Sci U S A (2006) 103(16):6293-8. doi:10.1073/ pnas.0511305103

9. Chung JB, Silverman M, Monroe JG. Transitional B cells: step by step towards immune competence. Trends Immunol (2003) 24(6):343-9. doi:10.1016/ S1471-4906(03)00119-4

10. Miller JP, Stadanlick JE, Cancro MP. Space, selection, and surveillance: setting boundaries with BLyS. JImmunol (2006) 176(11):6405-10. doi:10.4049/ jimmunol.176.11.6405

11. Deenen GJ, Kroese FG. Kinetics of peritoneal B-1a cells (CD5 B cells) in young adult mice. Eur J Immunol (1993) 23(1):12-6. doi:10.1002/eji.1830230104

12. Kantor AB, Stall AM, Adams S, Herzenberg LA, Herzenberg LA. Adoptive transfer of murine B-cell lineages. Ann N Y Acad Sci (1992) 651:168-9. doi:10.1111/j.1749-6632.1992.tb24610.x

13. Kantor AB, Stall AM, Adams S, Herzenberg LA, Herzenberg LA. Differential development of progenitor activity for three B-cell lineages. Proc Natl Acad Sci U S A (1992) 89(8):3320-4. doi:10.1073/pnas.89.8.3320

14. Ghosn EE, Yamamoto R, Hamanaka S, Yang Y, Herzenberg LA, Nakauchi H, et al. Distinct B-cell lineage commitment distinguishes adult bone marrow hematopoietic stem cells. Proc Natl Acad Sci U S A (2012) 109(14):5394-8. doi:10.1073/pnas.1121632109

15. Martin F, Oliver AM, Kearney JF. Marginal zone and B1 B cells unite in the early response against $\mathrm{T}$-independent blood-borne particulate antigens. Immunity (2001) 14(5):617-29. doi:10.1016/S1074-7613(01)00129-7

16. Choi YS, Baumgarth N. Dual role for B-1a cells in immunity to influenza virus infection. J Exp Med (2008) 205(13):3053-64. doi:10.1084/jem.20080979

17. Haas KM, Poe JC, Steeber DA, Tedder TF. B-1a and B-1b cells exhibit distinct developmental requirements and have unique functional roles in innate and adaptive immunity to S. pneumoniae. Immunity (2005) 23(1):7-18. doi:10.1016/j.immuni.2005.04.011

18. Duan B, Croker BP, Morel L. Lupus resistance is associated with marginal zone abnormalities in an NZM murine model. Lab Invest (2007) 87(1):14-28. doi:10.1038/labinvest. 3700497

19. Duan B, Morel L. Role of B-1a cells in autoimmunity. Autoimmun Rev (2006) 5(6):403-8. doi:10.1016/j.autrev.2005.10.007

20. Margry B, Wieland WH, van Kooten PJ, van Eden W, Broere F. Peritoneal cavity B-1a cells promote peripheral CD4+ T-cell activation. Eur J Immunol (2013) 43(9):2317-26. doi:10.1002/eji.201343418

21. Sato T, Ishikawa S, Akadegawa $\mathrm{K}$, Ito T, Yurino $\mathrm{H}$, Kitabatake $\mathrm{M}$, et al. Aberrant $\mathrm{B} 1$ cell migration into the thymus results in activation of CD4 $\mathrm{T}$ cells through its potent antigen-presenting activity in the development of murine lupus. Eur J Immunol (2004) 34(12):3346-58. doi:10.1002/eji.200425373

22. Vigna AF, Godoy LC, Rogerio de Almeida S, Mariano M, Lopes JD. Characterization of $\mathrm{B}-1 \mathrm{~b}$ cells as antigen presenting cells in the immune response to gp43 from Paracoccidioides brasiliensis in vitro. Immunol Lett (2002) 83(1):61-6. doi:10.1016/S0165-2478(02)00070-6

23. Wang Y, Rothstein TL. Induction of Th17 cell differentiation by B-1 cells. Front Immunol (2012) 3:281. doi:10.3389/fimmu.2012.00281

24. Zimecki M, Kapp JA. Presentation of antigen by B cell subsets. II. The role of CD5 B cells in the presentation of antigen to antigen-specific T cells. Arch Immunol Ther Exp (Warsz) (1994) 42(5-6):349-53.

25. Zimecki M, Whiteley PJ, Pierce CW, Kapp JA. Presentation of antigen by B cells subsets. I. Lyb-5+ and Lyb-5- B cells differ in ability to stimulate antigen specific T cells. Arch Immunol Ther Exp (Warsz) (1994) 42(2):115-23.

26. Ron Y, De Baetselier P, Gordon J, Feldman M, Segal S. Defective induction of antigen-reactive proliferating T cells in B cell-deprived mice. Eur J Immunol (1981) 11(12):964-8. doi:10.1002/eji.1830111203

27. Barr TA, Gray M, Gray D. B cells: programmers of CD4 T cell responses. Infect Disord Drug Targets (2012) 12(3):222-31. doi:10.2174/187152612800564446

28. Crawford A, Macleod M, Schumacher T, Corlett L, Gray D. Primary T cell expansion and differentiation in vivo requires antigen presentation by $\mathrm{B}$ cells. J Immunol (2006) 176(6):3498-506. doi:10.4049/jimmunol.176.6.3498

29. Epstein MM, Di Rosa F, Jankovic D, Sher A, Matzinger P. Successful T cell priming in B cell-deficient mice. J Exp Med (1995) 182(4):915-22. doi:10.1084/ jem.182.4.915

30. Rivera A, Chen CC, Ron N, Dougherty JP, Ron Y. Role of B cells as antigen-presenting cells in vivo revisited: antigen-specific $\mathrm{B}$ cells are essential for T cell expansion in lymph nodes and for systemic $\mathrm{T}$ cell responses to low antigen concentrations. Int Immunol (2001) 13(12):1583-93. doi:10.1093/ intimm/13.12.1583

31. Fuchs EJ, Matzinger P. B cells turn off virgin but not memory T cells. Science (1992) 258(5085):1156-9. doi:10.1126/science.1439825

32. Lassila O, Alanen A, Vainio O, Houssaint E, Pink JR, Weber WT. B cell precursors in chick embryos surgically bursectomized at $72 \mathrm{~h}$ of incubation. Eur J Immunol (1988) 18(11):1867-70. doi:10.1002/eji.1830181136

33. Kurt-Jones EA, Liano D, HayGlass KA, Benacerraf B, Sy MS, Abbas AK. The role of antigen-presenting B cells in T cell priming in vivo. Studies of B cell-deficient mice. J Immunol (1988) 140(11):3773-8.

34. Liu Y, Wu Y, Ramarathinam L, Guo Y, Huszar D, Trounstine M, et al. Genetargeted B-deficient mice reveal a critical role for B cells in the CD4 T cell response. Int Immunol (1995) 7(8):1353-62. doi:10.1093/intimm/7.8.1353

35. Topham DJ, Tripp RA, Hamilton-Easton AM, Sarawar SR, Doherty PC. Quantitative analysis of the influenza virus-specific $\mathrm{CD} 4+\mathrm{T}$ cell memory in the absence of B cells and Ig. J Immunol (1996) 157(7):2947-52.

36. Malynn BA, Romeo DT, Wortis HH. Antigen-specific B cells efficiently present low doses of antigen for induction of $\mathrm{T}$ cell proliferation. J Immunol (1985) 135(2):980-8.

37. Townsend SE, Goodnow CC. Abortive proliferation of rare T cells induced by direct or indirect antigen presentation by rare B cells in vivo. J Exp Med (1998) 187(10):1611-21. doi:10.1084/jem.187.10.1611

38. De Lorenzo BH, Brito RR, Godoy LC, Lopes JD, Mariano M. Tolerogenic property of B-1b cells in a model of allergic reaction. Immunol Lett (2007) 114(2):110-8. doi:10.1016/j.imlet.2007.09.013

39. Mussalem JS, Squaiella-Baptistao CC, Teixeira D, Yendo TM, Thies FG, Popi AF, et al. Adjuvant effect of killed Propionibacterium acnes on mouse peritoneal B-1 lymphocytes and their early phagocyte differentiation. PLoS One (2012) 7(3):e33955. doi:10.1371/journal.pone.0033955

40. Barr TA, Brown S, Mastroeni P, Gray D. TLR and B cell receptor signals to B cells differentially program primary and memory Th1 responses to Salmonella enterica. J Immunol (2010) 185(5):2783-9. doi:10.4049/jimmunol.1001431

41. Barr TA, Brown S, Ryan G, Zhao J, Gray D. TLR-mediated stimulation of APC: distinct cytokine responses of B cells and dendritic cells. Eur J Immunol (2007) 37(11):3040-53. doi:10.1002/eji.200636483

42. Gray D, Gray M, Barr T. Innate responses of B cells. Eur J Immunol (2007) 37(12):3304-10. doi:10.1002/eji.200737728

43. Wang LD, Clark MR. B-cell antigen-receptor signalling in lymphocyte development. Immunology (2003) 110(4):411-20. doi:10.1111/j.1365-2567.2003.01756.x

44. Alhakeem SS, Sindhava VJ, McKenna MK, Gachuki BW, Byrd JC, Muthusamy $\mathrm{N}$, et al. Role of B cell receptor signaling in IL-10 production by normal and malignant B-1 cells. Ann N Y Acad Sci (2015) 1362:239-49. doi:10.1111/ nyas. 12802

45. Holodick NE, Rothstein TL. Atypical response of B-1 cells to BCR ligation: a speculative model. Front Immunol (2013) 4:457. doi:10.3389/ fimmu.2013.00457

46. Sindhava VJ, Bondada S. Multiple regulatory mechanisms control B-1 B cell activation. Front Immunol (2012) 3:372. doi:10.3389/fimmu.2012.00372

47. Gao J, Ma X, Gu W, Fu M, An J, Xing Y, et al. Novel functions of murine B1 cells: active phagocytic and microbicidal abilities. Eur J Immunol (2012) 42(4):982-92. doi:10.1002/eji.201141519

48. Booth J, Wilson H, Jimbo S, Mutwiri G. Modulation of B cell responses by toll-like receptors. Cell Tissue Res (2011) 343(1):131-40. doi:10.1007/ s00441-010-1031-3

49. Fillatreau S, Manz RA. Tolls for B cells. Eur J Immunol (2006) 36(4):798-801. doi:10.1002/eji.200636040

50. Meyer-Bahlburg A, Rawlings DJ. Differential impact of toll-like receptor signaling on distinct B cell subpopulations. Front Biosci (Landmark Ed) (2012) 17:1499-516. doi:10.2741/4000

51. Genestier L, Taillardet M, Mondiere P, Gheit H, Bella C, Defrance T. TLR agonists selectively promote terminal plasma cell differentiation of B cell subsets specialized in thymus-independent responses. JImmunol (2007) 178(12):7779-86. doi:10.4049/jimmunol.178.12.7779

52. Avalos AM, Busconi L, Marshak-Rothstein A. Regulation of autoreactive B cell responses to endogenous TLR ligands. Autoimmunity (2010) 43(1):76-83. doi: $10.3109 / 08916930903374618$ 
53. Crampton SP, Voynova E, Bolland S. Innate pathways to B-cell activation and tolerance. Ann N Y Acad Sci (2010) 1183:58-68. doi:10.1111/j.1749-6632.2009.05123.x

54. Iwasaki A, Medzhitov R. Toll-like receptor control of the adaptive immune responses. Nat Immunol (2004) 5(10):987-95. doi:10.1038/ni1112

55. Webster GF. Inflammatory acne. Int J Dermatol (1990) 29(5):313-7. doi:10.11 11/j.1365-4362.1990.tb04749.x

56. Abath FG, Coutinho EM, Montenegro SM, Gomes YM, Carvalho AB. The use of non-specific immunopotentiators in experimental Trypanosoma cruzi infection. Trans R Soc Trop Med Hyg (1988) 82(1):73-6. doi:10.1016/0035-9203(88)90268-4

57. Brener Z, Cardoso JE. Nonspecific resistance against Trypanosoma cruzi enhanced by Corynebacterium parvum. JParasitol (1976) 62(4):645-6. doi: $10.2307 / 3279437$

58. Mussalem JS, Vasconcelos JR, Squaiella CC, Ananias RZ, Braga EG, Rodrigues $\mathrm{MM}$, et al. Adjuvant effect of the Propionibacterium acnes and its purified soluble polysaccharide on the immunization with plasmidial DNA containing a Trypanosoma cruzi gene. Microbiol Immunol (2006) 50(4):253-63. doi:10.11 11/j.1348-0421.2006.tb03791.x

59. Squaiella CC, Ananias RZ, Mussalem JS, Braga EG, Rodrigues EG, Travassos LR, et al. In vivo and in vitro effect of killed Propionibacterium acnes and its purified soluble polysaccharide on mouse bone marrow stem cells and dendritic cell differentiation. Immunobiology (2006) 211(1-2):105-16. doi:10.1016/j.imbio.2005.10.013

60. Halpern BN, Biozzi G, Stiffel C, Mouton D. Inhibition of tumour growth by administration of killed Corynebacterium parvum. Nature (1966) 212(5064):853-4. doi:10.1038/212853a0

61. Nussenzweig RS. Increased nonspecific resistance to malaria produced by administration of killed Corynebacterium parvum. Exp Parasitol (1967) 21(2):224-31. doi:10.1016/0014-4894(67)90084-7

62. Smith SR, Calzetta A, Bankowski J, Kenworthy-Bott L, Terminelli C. Lipopolysaccharide-induced cytokine production and mortality in mice treated with Corynebacterium parvum. J Leukoc Biol (1993) 54(1):23-9.

63. Warr GW, James K. Effect of Corynebacterium parvum on the class and subclass of antibody produced in the response of different strains of mice to sheep erythrocytes. Immunology (1975) 28(3):431-42.

64. Braga EG, Ananias RZ, Mussalem JS, Squaiella CC, Longhini AL, Mariano M, et al. Treatment with Propionibacterium acnes modulates the late phase reaction of immediate hypersensitivity in mice. Immunol Lett (2003) 88(2):163-9. doi:10.1016/S0165-2478(03)00079-8

65. Squaiella CC, Longhini AL, Braga EG, Mussalem JS, Ananias RZ, Yendo TM, et al. Modulation of the type I hypersensitivity late phase reaction to OVA by Propionibacterium acnes-soluble polysaccharide. Immunol Lett (2008) 121(2):157-66. doi:10.1016/j.imlet.2008.10.005

66. Kalis C, Gumenscheimer M, Freudenberg N, Tchaptchet S, Fejer G, Heit A, et al. Requirement for TLR9 in the immunomodulatory activity of Propionibacterium acnes. J Immunol (2005) 174(7):4295-300. doi:10.4049/ jimmunol.174.7.4295

67. Kim J, Ochoa MT, Krutzik SR, Takeuchi O, Uematsu S, Legaspi AJ, et al. Activation of toll-like receptor 2 in acne triggers inflammatory cytokine responses. JImmunol (2002) 169(3):1535-41. doi:10.4049/ jimmunol.169.3.1535

68. Squaiella-Baptistao CC, Teixeira D, Mussalem JS, Ishimura ME,Longo-Maugeri IM. Modulation of Th1/Th2 immune responses by killed Propionibacterium acnes and its soluble polysaccharide fraction in a type I hypersensitivity murine model: induction of different activation status of antigen-presenting cells. J Immunol Res (2015) 2015:132083. doi:10.1155/2015/132083

69. Popi AF, Motta FLT, Mortara RA, Schenkman S, Lopes JD, Mariano M. Co-ordinated expression of lymphoid and myeloid specific transcription factors during B-1b cell differentiation into mononuclear phagocytes in vitro. Immunology (2009) 126(1):114-22. doi:10.1111/j.1365-2567.2008.02883.x

70. Popi AF, Osugui L, Perez KR, Longo-Maugeri IM, Mariano M. Could a B-1 cell derived phagocyte "be one" of the peritoneal macrophages during LPS-driven inflammation? PLoS One (2012) 7(3):e34570. doi:10.1371/journal.pone.0034570

71. Ng LG, Ng CH, Woehl B, Sutherland AP, Huo J, Xu S, et al. BAFF costimulation of toll-like receptor-activated B-1 cells. Eur J Immunol (2006) 36(7):1837-46. doi:10.1002/eji.200635956

72. Tumang JR, Hastings WD, Bai C, Rothstein TL. Peritoneal and splenic B-1 cells are separable by phenotypic, functional, and transcriptomic characteristics. Eur J Immunol (2004) 34(8):2158-67. doi:10.1002/eji.200424819

73. Zhong X, Gao W, Degauque N, Bai C, Lu Y, Kenny J, et al. Reciprocal generation of Th1/Th17 and T(reg) cells by B1 and B2 B cells. Eur J Immunol (2007) 37(9):2400-4. doi:10.1002/eji.200737296

74. Zhu LY, Lin AF, Shao T, Nie L, Dong WR, Xiang LX, et al. B cells in teleost fish act as pivotal initiating APCs in priming adaptive immunity: an evolutionary perspective on the origin of the B-1 cell subset and B7 molecules. J Immunol (2014) 192(6):2699-714. doi:10.4049/jimmunol.1301312

75. Almeida SR, Aroeira LS, Frymuller E, Dias MA, Bogsan CS, Lopes JD, et al. Mouse B-1 cell-derived mononuclear phagocyte, a novel cellular component of acute non-specific inflammatory exudate. Int Immunol (2001) 13(9):1193201. doi:10.1093/intimm/13.9.1193

76. Ansel KM, Harris RB, Cyster JG. CXCL13 is required for B1 cell homing, natural antibody production, and body cavity immunity. Immunity (2002) 16(1):67-76. doi:10.1016/S1074-7613(01)00257-6

77. Labadi A, Balogh P. Differential preferences in serosal homing and distribution of peritoneal B-cell subsets revealed by in situ CFSE labeling. Int Immunol (2009) 21(9):1047-56. doi:10.1093/intimm/dxp071

78. Lampropoulou V, Hoehlig K, Roch T, Neves P, Calderon Gomez E, Sweenie $\mathrm{CH}$, et al. TLR-activated B cells suppress $\mathrm{T}$ cell-mediated autoimmunity. J Immunol (2008) 180(7):4763-73. doi:10.4049/jimmunol.180.7.4763

79. Fillatreau S, Sweenie CH, McGeachy MJ, Gray D, Anderton SM. B cells regulate autoimmunity by provision of IL-10. Nat Immunol (2002) 3(10):944-50. doi: $10.1038 /$ ni833

80. Popi AF, Godoy LC, Xander P, Lopes JD, Mariano M. B-1 cells facilitate Paracoccidioides brasiliensis infection in mice via IL-10 secretion. Microb Infect (2008) 10(7):817-24. doi:10.1016/j.micinf.2008.04.012

81. Popi AF, Zamboni DS, Mortara RA, Mariano M. Microbicidal property of B1 cell derived mononuclear phagocyte. Immunobiology (2009) 214(8):664-73. doi:10.1016/j.imbio.2008.12.007

Conflict of Interest Statement: The authors declare that the research was conducted in the absence of any commercial or financial relationships that could be construed as a potential conflict of interest.

Copyright (C) 2016 Popi, Longo-Maugéri and Mariano. This is an open-access article distributed under the terms of the Creative Commons Attribution License (CC BY). The use, distribution or reproduction in other forums is permitted, provided the original author(s) or licensor are credited and that the original publication in this journal is cited, in accordance with accepted academic practice. No use, distribution or reproduction is permitted which does not comply with these terms. 